\title{
How Many More Brumadinhos and Marianas Will We be Faced with Yet?
}

Almost three years ago, an editorial in the Journal of the Brazilian Chemical Society ${ }^{1}$ discussed the environmental consequences of the November 5, 2015 catastrophic failure of the Fundão Dam, located in Mariana-MG and owned by Samarco (a joint venture of Vale and BHP Billiton), which resulted in the death of 19 people and rendered more than 300 families homeless. This was one of the worst environmental disasters ever to occur in Brazil. Thousands of tons of iron ore tailings invaded the Doce River basin, reaching all the way to the Atlantic coast near the mouth of the river. This watershed has not yet fully recovered, and the environmental impacts are frequently reported in the scientific literature (see e.g. Quadra et al.) $)^{2}$ and by the media.

Although another disaster of that magnitude was not expected by the Brazilian society, on January 25, 2019 a second such dam catastrophically failed. This time at the Córrego do Feijão iron ore mine (owned only by Vale), in Brumadinho-MG, causing the unfortunate disappearance of about 300 people (many of whom are still missing). The human and social impacts of this catastrophe are immeasurable, being significantly greater than the one in Mariana, and we at the Brazilian Chemical Society (SBQ) do sympathize with all those affected by this very sad incident, although no action can repair the pain of the families in relation to their losses. We do hope no more failings of mining tailings dams occur in our country, rendering environmental impacts and human losses.

Disasters of the magnitude of the Brumadinho Dam collapse leave as inheritance huge impacts on the local watershed and great losses for those who live in the surrounding areas. The actual environmental impacts are still being evaluated, but possibly will not be as serious as the Mariana disaster. Nevertheless, those environmental problems must not be minimized, once a large number of families will no longer be able to make a living in that region. The tailings mud reached the Paraopeba River, which is one of the tributaries of the São Francisco one. The images of complete destruction of the aquatic fauna were shocking and only one thing could be thought about the small agricultural properties that depend on the Paraopeba River: when will it be possible again to secure their productions?

At this moment, governmental bodies at all levels continue working intensively to find solutions, to analyze the responsibility of the key actors involved, and to present courses of action for punishment as well as for policy changes. Unfortunately, once again we were running after the problem. The Mariana disaster should have brought significant changes of conduct, since active and firm inspections by the state should be the way to have effective diagnostics and prevention of any rupture of mining tailings dams. The prevention of such disasters must be a state policy, instead of a policy of a given government, something that unfortunately is not the norm in Brazil. More commonly, there have been omissions at one or more governmental levels, as seen in several of the recent tragedies. Surely, we do not need to be faced with other disasters like Mariana and Brumadinho to act.

It should also be noted that the new federal government was elected with the promise of expanding mining activities, which undoubtedly have a strong impact on the country's economy. On the other hand, 
the Ministry of the Environment (MMA) was almost deactivated and merged with another ministry. At this moment, there should be a deep reflection on the importance of sustainable growth, and on the need not only to maintain a specific Ministry for the Environment, but also to strengthen this structure in all its levels. It should be remembered that the slowness of the licensing system disrupts the productive sector, but at the same time does not allow effective actions in the inspection of environmental problems. This could be largely solved by allocating enough public servants in the MMA. It is no use to maintain and improve the legal structure without qualified actors to enforce their roles.

We would like to conclude by recalling that the Brazilian Chemical Society, which among its members has several researchers with relevant technical knowledge, is ready to contribute to the national discussions in search of the needed solutions, from the point of view of their qualifications in chemistry. At this critical moment, we must expect of each public agent the due fulfillment of his/her role in the protection of the Brazilian people and of the environmental and material heritage represented by the natural resources of our country. The Brumadinho disaster must not become another demonstration that the wealthy and powerful are above the law and that, in Brazil, public officials omit themselves, hidden by arguments that offend the citizenry.

Norberto Peporine Lopes

President of the Brazilian Chemical Society

Universidade de São Paulo (USP),

Ribeirão Preto-SP, Brazil

Rossimiriam Pereira de Freitas

Vice-President of the Brazilian Chemical Society Universidade Federal de Minas Gerais (UFMG), Belo Horizonte-MG, Brazil

\section{Romeu Cardozo Rocha Filho}

President-Elect of the Brazilian Chemical Society Universidade Federal de São Carlos (UFSCar),

São Carlos-SP, Brazil

\section{References}

1. Hatje, V.; J. Braz. Chem. Soc. 2016, 27, 1137.

2. Quadra, G. R.; Roland, F.; Barros, N.; Malm, O.; Lino, A. S.; Azevedo, G. M.; Thomaz, J. R.; Andrade-Vieira, L. F.; PraçaFontes, M. M.; Almeida, R. M.; Mendonça, R. F.; Cardoso, S. J.; Guida, Y. S.; Campos, J. M. S.; Chemosphere 2019, 215, 753. 